\title{
STUDY OF THE CLINICOPATHOLOGICAL PROFILE OF PAEDIATRIC HAEMATOLOGICAL MALIGNANCIES AT A TERTIARY CARE CENTRE
}

Hegde Shruti S1, Soundarya $\mathrm{P}^{2}$, Hars ha $\mathrm{K}^{3}$

\section{HOW TO CITE THIS ARTICLE:}

Hegde Shruti S, Soundarya P, Harsha K. "Study of the clinicopathological profile of paediatric haematological malignancies at a tertiary care centre". Journal of Evolution of Medical and Dental Sciences 2013; Vol2, Issue 43, October 28; Page: 8438-8443.

ABSTRACT: Introduction: Leukaemia's (Acute Lymphocytic Leukaemia i.e., ALL, Acute Myeloblastic Leukaemia i.e., AML and Burkitt's) are common during childhood. There are very few studies in recent past correlating the symptoms and laboratory findings to the specific types of acute leukaemia's Indian population. OBJECTIVE: The present study was aimed at analysing the presenting features, laboratory findings in correlation with the final diagnosis as determined by the flow cytometric analysis. STUDY DESIGN: Retrospective Study, STUDY SETTING: Tertiary care hospital. PARTICIPANT: Children who were diagnosed to have leukemia. METHODS: The Performa was used to record the clinical \& pathological profile. RESULTS: ALL was found to be the most common type of haematological malignancy in children. Among the ALL, B-Cell formed the majority and $92.3 \%$ of B-cell ALL were CALLA positive. Fever was found to be the most common symptom and pallor the most common sign. The most common site of extramedullary involvement was found to be the spleen. Anaemia and thrombocytopenia was found in majority of the cases. All cases had hypercellular marrow at the time of diagnosis.

INTRODUCTION: Acute leukemia is the most common childhood hematological malignancy, representing close to $35 \%$ of all childhood cancers. The mean annual incidence rate of acute leukemia's is 4-7 children/100000[1]. Data analysis of cancer registry has shown that leukemia is most common childhood malignancy [2].

The pattern of clinical presentation of these malignancies is variable and depends largely on the nature of the disease and its extent. There are very few studies correlating the symptoms and lab findings to the specific types of acute leukemia's. The present study is aimed at analyzing the presenting features, laboratory findings in correlation with the final diagnosis as determined by the flow cytometric analysis.

MATERIALS \& METHODS: The Present Retrospective record based Study Was Carried out in the Department of Pediatrics, Kasturba Medical College, Attavar, and Mangalore. Records of children between the age of 1 to15 years diagnosed to have Acute Leukemia i.e. Acute Lymphoblastic Leukemia (ALL), Acute Myeloblastic Leukemia (AML) And Biphenotypic by peripheral smear, bone marrow and flow cytometry during 2008-2010 were studied. Suspected Leukemia not confirmed by flow cytometry was excluded from the study.

Following operational definitions were used:

1. Leukocyte counts of 4000 - 10000 cells/cu mm were considered as normal reference range of our laboratory.

2. FAB (French, American British) classification was used to differentiate leukemias [3].

3. Acute leukemia: $>20 \%$ of the blasts in bone marrow [3]. 
4. Acute lymphoblastic leukemia (ALL) :> 20\% of lymphoblast's in bone marrow [4].

5. Acute myeloblastic leukemia (AML) :> 20\% of myeloblasts in bone marrow [4].

6. Hyper leucocytosis: WBC count $>100000 / \mathrm{cu} \mathrm{mm} \mathrm{[5].}$

7. Grading of Anemia ( $\mathrm{Hb}$ in gms / dl): Mild $>10$ but $<$ normal for age, Moderate 7-10, and Severe< 7[6].

8. Lymphadenopathy (Size in Millimeters): $>10$ in its greatest diameter. Exceptions are: Trochlear nodes: $5 \mathrm{~mm}$ and inguinal15mm [7].

A semi-structured Performa was designed to collect the following components of information : Basic patient characteristics (Age, sex etc..), Information about the clinical profile like presenting complaints, clinical signs, investigations, Co-morbidities and Complications, if any associated with leukemia. This semi-structured Performa was pretested on admitted cases in wards and appropriate changes made to suit our circumstances. After obtaining permission from the institutional ethics committee, the hospital records from the period of 2008-2010 were accessed and the required information was copied down in the Performa. Basic patient characteristics were expressed as proportions.

RESULTS: There were 62 children between 1- 15 years who fulfilled the inclusion criteria. Totally 51(82.3\%) had ALL, 7 (11.3\%) were AML and 4 (6.5\%) had biphenotypic leukemia. Among the ALL types B-Cell formed the majority 39(76.5\%) followed by T-Cell, 8 (15.7\%) and Burkitt's, 4 (7.8\%).

Numbers (n) of children and the age ranges (yrs - yrs) are depicted here: 8(0-2) \& 6(>10-15). Of the 41 male patients, 4 were below 2 years at the time of diagnosis and 2 were $=15$ years. Majority of the male patients belonged to age group of 2-10 years. Out of 21 female patients 2 were above 10 years and the rest belonged to the age group of 2-10years.

The presenting symptoms and signs of the disease were quite variable, with most of them pertaining to degree of bone marrow failure or extent of extramedullary spread or organ infiltration. Among the presenting symptoms, infections related symptoms like fever, Upper Respiratory Tract Infections, Lower respiratory tract infections and Gastro intestinal infections were most common 57(91.9\%) Fever and respiratory infections followed by anemia were the most common presenting features in almost all type of leukemia's. Skin bleed (petechiae, purpura and ecchymosis) was more common in B cell 38(97.4\%), where as both skin and frank bleeding (gum bleeding) was of same frequency in AML 5(71.4\%). One case of ALL out of 51 presented with testicular involvement and one child had multiple cafe-au-lait spots. Liver and spleen were the most common sites of extramedullary involvement and were enlarged in more than two thirds of patients at diagnosis. Lymphadenopathy was the most common finding in children with biphenotypic leukemia (100\%).None of the children with Burkitt's presented with lymphadenopathy as all the Burkitt's were of gastrointestinal type. Abdominal distension due to hepatosplenomegaly was found in all the types of leukemia's. All the children of biphenotypic and AML presented with hepatomegaly. Massive hepatomegaly of $>10 \mathrm{~cm}$ below the right costal margin was found in 2 cases of biphenotypic and one case of AML.

Severe anemia was more common in AML 7(87.5\%). TLC at diagnosis ranged widely from less than $15000 / \mathrm{cu} \mathrm{mm}$ to $>1000000 / \mathrm{cu} \mathrm{mm}$. Hyperleukocytosis was common in $\mathrm{T}$ cell leukemia(50\%) indicating high tumor cell burden and increased risk of tumor lysis syndrome. 
Peripheral smear of 54 out of 62 patients (87.1\%) showed a blast count of more than $50 \%$. All cases showed a leukemic presentation with $100 \%$ cases of hypercellular marrow. None of the cases had an aplastic presentation of the marrow. Among the patients of AML, M2 was the most common picture. There were 4 children who were diagnosed as lymphoma leukemia syndrome. Increased creatinine levels suggesting acute renal failure was the finding in 25\% of T cell ALL (2) and Burkitt's (1) respectively (Table-1).

Amongst the B-Cell ALL 36(92.31\%) were CALLA (CD10) positive, 38(97.44\%) were CD19 positive, $30(76.92 \%)$ were CD10/19 positive, $21(53.85 \%)$ were CD41 positive and $8(20.51 \%)$ were CD7 positive. Out of 8 who were diagnosed to have T-Cell ALL 7(87.5\%) were CD45 positive and $5(62.5 \%)$ were CD3 positive. Among the 7 AML cases $5(71.43 \%)$ were CD33 positive and $4(57.14 \%)$ were CD13 positive. $4(100 \%)$ of the 4 biphenotypic leukemia's were found to be CD13 positive and $3(75 \%)$ were CD33 positive.

DISCUSSION: At present the diagnosis and classification of acute leukemia is mainly based on the immunophenotype of the leukemic blasts. In the present study, it was found that among the acute leukemia's ALL was found to be the most common followed by AML (11.3\%), biphenotypic (6.5\%), burkitts (6.5\%). Among ALL B cell formed the majority (62.9\%) followed by T cell (12.9\%). 92.3\% of $B$ cell ALL was found to express the CALLA antigen and rest of the B cell were CALLA negative. This observation is comparable to the finding of Sudharaniet al [8], whose study revealed $62.5 \%$ of leukemia to be ALL and $29.5 \%$ were AML.

Of the 62 cases $41(66.1 \%)$ were male and 21(33.9\%) were females giving male to female ratio of 1.95:1. Other studies throughout the world also show male preponderance [9-14]. Study of Jusawalla et al Bombay gives M: F ratio of 1.4:1 [10]. Studies like CCG [11] and St.Judes [12] also showed male preponderance in childhood malignancies. In the present study the most commonly affected age group was in the range of 2 to 8 years with the peak incidence of 5 years. Our study is again comparable to the Bombay study [10] which showed incidence in the $0-9$ age group as $71.4 \%$ and $9-15$ age groups as $28.6 \%$.

Anemia, fever, bleeding manifestations and organomegaly were most frequent manifestations of the disease noted in the subjects in this study and the same has been observed in the various other studies done earlier [5,8,11,13,15].Bone and joint pains were in the least prominent symptoms in our study. In the present study one case presented with the Testicular enlargement indicating a high tumor burden at the time of diagnosis and one with multiple neurocutaneous markers (multiple cafe-au-lait spots) and a strong family history of malignancy. However there were no such cases reported in CCG study [11].

Severe anemia \& thrombocytopenia are common presenting features as found in previous studies as well [8, 9, and 15]. Leukocytosis (TLC $>10,000 / \mathrm{mm}^{3}$ ) was noted in $35.5 \%$ and hyperleukocytosis was observed in $21 \%$ cases of acute leukemia. Robinson observed leukocytosis in $45 \%$ and hyperleukocytosis in $10 \%$ of the cases. In AML $42.9 \%$ children had leukocytosis and $28.6 \%$ had Hyperleukocytosis [9]. Simone and SI Choi had observed 21\% of the patients with AML to have TLC more than $100000 / \mathrm{cu} \mathrm{mm}$ [15].

To our knowledge this is first study in India reporting various CD markers. 
CONCLUSION: In conclusion, ALL was found to be the most common type of haematological malignancy in children. Among the ALL B-Cell formed the majority and $92.3 \%$ of B-cell ALL were CALLA positive. There was a male preponderance with the male to female ratio of 2:1. Fever was found to be the most common symptom and pallor the most common sign. The most common site of extramedullary involvement was found to be the spleen. Anaemia and thrombocytopenia was found in majority of the cases. All cases had hypercellular marrow at the time of diagnosis.

\begin{tabular}{|c|c|}
\hline $\begin{array}{l}\text { What is } \\
\text { known : }\end{array}$ & $\begin{array}{l}\text { Acute lymphoblastic leukemia is the most common childhood malignancy. } \\
\text { With the male to female ratio of } 2: 1 \\
\text { Most common age group affected was 2-10 years. } \\
\text { Fever, bleeding manifestations, organomegaly, anemia and thrombocytopenia } \\
\text { were the most common findings. }\end{array}$ \\
\hline $\begin{array}{l}\text { What the } \\
\text { study adds: }\end{array}$ & $\begin{array}{l}>\text { Our study reinforces the findings of the studies done earlier. } \\
>\text { Amongst the B-Cell ALL 36(92.31\%) were CALLA (CD10) positive, 38(97.44\%) } \\
\text { were CD19 positive, 30(76.92\%) were CD10/19 positive, } 21(53.85 \%) \text { were CD } 41 \\
\text { positive and } 8(20.51 \%) \text { were CD7 positive. } \\
>\text { Out of } 8 \text { who were diagnosed to have T-Cell ALL } 7(87.5 \%) \text { were CD45 positive and } \\
5(62.5 \%) \text { were CD3 positive. } \\
>\text { Among the } 7 \text { AML cases } 5(71.43 \%) \text { were CD33 positive and } 4(57.14 \%) \text { were CD13 } \\
\text { positive. } \\
>4(100 \%) \text { of the } 4 \text { biphenotypic leukemia's were found to be CD13 positive and } \\
3(75 \%) \text { were CD33 positive }\end{array}$ \\
\hline
\end{tabular}

\section{REFERENCES:}

1. Pravin D. Potdar, Rambhadur P. Subedi. Defining Molecular Phenotypes of Mesenchymal and Hematopoietic Stem cells derived from Acute Lymphoblastic Leukemia patients for regenerative stem cell therapy. Journal of Stem Cells \& Regenerative Medicine 2011; 7:2940.

2. Datta K, Choudhuri M, Guha S, Biswas J. Childhood cancer burden in part of eastern India-Population Based Cancer Registry data for Kolkata (1997-2004).Asian Pac J Cancer Prev. 2010; 11:1283-8.

3. Ward G. The infective theory of acute leukemia. Br. J. Child Dis. 1917; 14: 10-20.

4. Crowther D, Bateman CJ, Vartan CP, Whitehouse JM, Malpas JS, Fairley GH et al. Combination chemotherapy using L-asparaginase, daunorubicin, and cytosine arabinoside in adults with acute myelogenous leukaemia.Br Med J. 1970;4:513-7.

5. GauriKapoor. Supportive care for children with leukemias at diagnosis and during therapy at peripheral centres. Indian Journal of Medical \&Paediatric Oncology 2004; 25:24-26.

6. Preud 'home JL, Seligmann M. Surface bound immunoglobulins as a cell marker in human lymphoproliferative diseases. Blood 1972; 40:777-794.

7. Borella L, Sen L. T cell surface markers on lymphoblasts from acute lymphocytic leukemia. J. Immunol 1973; 111: 1257-60.

8. Rani S, Beohar PC, Mohanty TK. Leukemia in children - a ten-year study. Indian Pediatr 1981 Jul; 18:461-6. 
9. Dores GM, Devesa SS, Curtis RE, Linet MS, Morton LM. Acute leukemia incidence and patient survival among children and adults in the United States, 2001-2007. Blood 2012; 119:34-43.

10. 10. Jussawalla DJ, Yeole BB, Natekar MV. Cancer in children in greater Bombay (1964-72). A comparative study. Indian J Cancer. 1975;12:135-43

11. Miller DR, Leikin S, Albo V, Sather H, Karon M, Hammond D. Prognostic factors and therapy in acute lymphoblastic leukemia of childhood: CCG-141. A report from children's cancer study group. Cancer. 1983 Mar 15; 51:1041-9.

12. 12. Pui CH, Boyett JM, Rivera GK, Hancock ML, Sandlund JT, Ribeiro RC et al. Long-term results of Total Therapy studies 11, 12 and 13A for childhood acute lymphoblastic leukemia at St. Jude Children's Research Hospital. Leukemia. 2000; 14:2286-94.

13. Milller DR. Acute Lymphoblastic Leukemia. PediatrClin North Am. 1980; 27:269-91.

14. 14. Rogalsky R.J, Black GB, Reed MH. Orthopaedic manifestations of leukemia in children. J Bone Joint Surg Am. 1986; 68:494-501.

15. Choi SI, Simone JV. Acute nonlymphocytic leukemia in 171 children. Med PediatrOncol 1976; 2:119-46.

Table 1: Lab investigation of the Patients

\begin{tabular}{|c|c|c|c|c|c|}
\hline \multirow{2}{*}{$\begin{array}{c}\text { Clinical \& } \\
\text { Lab Characteristics }\end{array}$} & \multicolumn{3}{|c|}{ ALL } & \multirow[b]{2}{*}{$\begin{array}{l}\text { AML } \\
(N=8)\end{array}$} & \multirow[b]{2}{*}{$\begin{array}{l}\text { Biphenotypic } \\
(\mathrm{N}=8)\end{array}$} \\
\hline & $\begin{array}{c}\text { B Cell } \\
(N=39)\end{array}$ & $\begin{array}{l}\text { T Cell } \\
(N=8)\end{array}$ & $\begin{array}{c}\text { Burkitt's } \\
(\mathrm{N}=4)\end{array}$ & & \\
\hline $\begin{array}{l}\text { Total WBC count: } \\
\text { Leucopenia } \\
\text { Leukocytosis } \\
\text { hyperleukocytosis }\end{array}$ & $\begin{array}{c}18(46.2 \%) \\
5(12.8 \%) \\
16(41 \%)\end{array}$ & $\begin{array}{c}3(37.5 \%) \\
1(12.5 \%) \\
4(50 \%)\end{array}$ & $\begin{array}{c}3(75 \%) \\
0 \\
1(25 \%)\end{array}$ & $\begin{array}{l}2(25 \%) \\
3(37.5) \\
2(25 \%)\end{array}$ & $\begin{array}{c}1(12.5 \%) \\
3(37.5 \%) \\
0\end{array}$ \\
\hline $\begin{array}{l}\text { Platelet count: } \\
<10000 \\
10000-50000 \\
50000-100000 \\
100000-150000 \\
200000-150000\end{array}$ & $\begin{array}{c}13(33.33 \%) \\
15(38.5 \%) \\
2(5.13 \%) \\
1(2.6 \%) \\
8(20.5 \%)\end{array}$ & $\begin{array}{c}0 \\
4(50 \%) \\
2(25 \%) \\
2(25 \%) \\
0\end{array}$ & $\begin{array}{c}0 \\
1(25 \%) \\
0 \\
0 \\
2(50 \%)\end{array}$ & $\begin{array}{c}2(25 \%) \\
0 \\
2(25 \%) \\
4(50 \%) \\
0\end{array}$ & $\begin{array}{c}0 \\
2(25 \%) \\
1(12.5 \%) \\
1(12.5 \%) \\
0\end{array}$ \\
\hline Bone marrow PAS stain & 35 & 8 & 0 & 0 & $4(50 \%)$ \\
\hline Bone Marrow MPO staining & 2 & 0 & 0 & 3 & $2(25 \%)$ \\
\hline Bone Marrow sudan black stain & 39 & 0 & 0 & 3 & $2(25 \%)$ \\
\hline
\end{tabular}




\section{AUTHORS:}

1. Hegde Shruti $S$

2. Soundarya $\mathrm{P}$

3. Harsha $\mathrm{K}$

\section{PARTICULARS OF CONTRIBUTORS:}

1. PG Student, Department of Pediatrics, Kasturba Medical College, Manipal University.

2. Assistant Professor, Department of Community Medicine, Kasturba Medical College, Manipal University.

3. Assistant Professor, Department of Pediatrics, Kasturba Medical College, Manipal University.

\section{NAME ADDRESS EMAIL ID OF THE} CORRESPONDING AUTHOR:

Dr. Shruti S. Hegde, A-506, RNS Shanti Nivas,

Tumkur Road, Post

Yeshwanth pur, Bangalore - 560022 .

Email - shruti.hegde1587@gmail.com

Date of Submission: 21/08/2013.

Date of Peer Review: 22/08/2013.

Date of Acceptance: 24/08/2013.

Date of Publishing: 28/10/2013 